\title{
Studies on the Identification of Constituents in Ethanol Extract of Radix Glycyrrhizae and Their Anti-Primary Hepatoma Cell Susceptibility
}

\author{
Jie Liu \\ Department of Laboratory, The Military General Hospital of Beijing People's Liberation Army, No. 5 Nanmencang, Dongcheng District, \\ Beijing 100700, China \\ Correspondence should be addressed to Jie Liu; qjeionbjio@yeah.net
}

Received 2 April 2014; Revised 29 April 2014; Accepted 12 May 2014; Published 28 May 2014

Academic Editor: Bartolo Gabriele

Copyright (C) 2014 Jie Liu. This is an open access article distributed under the Creative Commons Attribution License, which permits unrestricted use, distribution, and reproduction in any medium, provided the original work is properly cited.

\begin{abstract}
The objective of this paper is to study the chemical constituents of Radix Glycyrrhizae and to apply the resulting natural products in the study of drug susceptibility of hepatoma cells so as to provide a scientific basis for quality standards and clinical application of medicinal Radix Glycyrrhizae. Chromatographic materials were used for isolation and purification; structural identification was performed based on physicochemical properties and spectral data. MTT colorimetry was used to detect the proliferation inhibition rate against primary hepatoma cells by natural products, and flow cytometry was used to detect the changes in cell cycle progression. Five compounds were isolated and identified, namely, liquiritigenin (1), liquiritin (2), isoliquiritigenin (3), betulinic acid (4), and oleanolic acid (5). In the study, 5-FU (5-fluorouracil) is used as a positive control to the hepatoma cells. Primary hepatoma cells were highly susceptible to 5-FU and liquiritigenin, both of which markedly inhibited the proliferation of hepatoma cells; flow cytometry results showed an increase in G0/G1 phase cells, a decrease in S phase cells, and a relative increase in G2/M phase cells. Primary hepatoma cells are highly susceptible to liquiritigenin, a natural product; the testing of tumor cell susceptibility is of important significance to the improvement of therapeutic effect of cancer.
\end{abstract}

\section{Introduction}

Radix Glycyrrhizae is a legume, which is recorded in the Chinese Pharmacopoeia 2010 Edition Vol. I as the root and rhizome of Glycyrrhiza uralensis Fisch., G. inflata Bat., or G. glabra L. [1]. Radix Glycyrrhizae has a complex chemical composition, whose main constituents are flavonoids and saponins [2-4]. Despite extensive studies on chemical constituents of Radix Glycyrrhizae, pharmacological studies on monomeric compounds, especially the studies on anticancer activities and drug susceptibility, are still few [5]. To further improve the quality evaluation of Radix Glycyrrhizae and to better guide clinical medication, a systematic study of chemical constituents in Radix Glycyrrhizae is necessary, in order to obtain monomeric compounds and to study their antihepatoma activities.

Primary liver cancer is a common malignancy. Incidence of liver cancer is relatively high in many countries, and the majority of patients are not diagnosed until they are in the advanced stages. Liver cancer is relatively less sensitive to chemotherapy and is prone to drug resistance, which forms major reasons affecting chemotherapeutic effect on liver cancer. Among them, the multidrug resistance (MDR) of liver cancer not only limits the chemotherapeutic effect on liver cancer, but is also an important cause of recurrence and metastasis of liver cancer. Human hepatoma Bel-7402 cell line has become one of the commonly used in vitro biological models in the screening of novel anticancer drug candidates. Domestic scholars have used this model to screen out baicalin, cordycepin, melittin, ampelopsin, ligustrazine, and other natural active constituents with relatively high inhibitory activities on hepatoma Bel-7402 cells from natural medicines and explored their application values in adjuvant therapy, susceptibility, and other aspects of liver cancer [6, 7]. In this study, hepatoma tissues obtained from surgical resection were used to prepare and culture primary hepatoma 
cells, which were used to perform anticancer drug sensitivity test, with the aim of improving drug efficacy and reducing side effects.

\section{Methods}

2.1. Instruments. NMR spectra were determined using a Bruker AV-500 NMR Spectrometer. TLC silica gel GF-254 and column chromatography silica gel (200-mesh) were both manufactured by Xindi Chemical Plant in Yantai; RPTLC plates were products of Merck, Germany; Sephadex LH-20 was a product of Pharmacia; RP-18 reversed phase silica gel was a product of Great Door, Germany; MCI GEL CHP-20P was a product of Mitsubishi Chemical; and D101 macroporous resin is a product of Dashi Technology Development Co., Ltd. in Nanjing.

2.2. Drugs and Reagents. Radix Glycyrrhizae was purchased from Hebei Ecological Technology Co., Ltd., which was identified by Professor Deng Fei from the Beijing University of Chinese Medicine as the root and rhizome of Glycyrrhiza uralensis Fisch. All the reagents used were of analytical grade. Five cases of hepatoma tissues were provided by the Department of Laboratory, General Hospital of Beijing Military Region of PLA, which had been pathologically diagnosed; RPMI-1640 medium and MTT reagents were purchased from Sigma; 5-FU (5-fluorouracil) was purchased from the Department of Pharmacy, General Hospital of Beijing Military Region of PLA; fetal bovine serum was purchased from Beijing Lixiapu Biology Co., Ltd.

\subsection{Preparation of Compounds}

2.3.1. Extraction and Isolation. Radix Glycyrrhizae medicinal material was ground, passed through a 60-mesh sieve, soaked overnight in a 6 -fold volume of $80 \%$ aqueous solution of ethanol, and then extracted under reflux three times, each time lasted $2 \mathrm{~h}$, followed by filtration. Solvent was then removed under reduced pressure to give the extract.

The $80 \%$ ethanol solution extract was dried to give the powder $(0.5 \mathrm{~kg})$, which was then fully dissolved in water, loaded on the D101 macroporous resin column, and eluted sequentially with water and 30\%, 60\%, and 90\% aqueous solutions of ethanol. The fraction eluted with $90 \%$ ethanol solution was isolated through silica gel column chromatography and gradient-eluted with cyclohexane-acetone $(10: 1$; $9: 1 ; 8: 1 ; 7: 1 ; 6: 1 ; 5: 1 ; 4: 1 ; 3: 1 ; 2: 1 ; 1: 1)$ to give compound $4(100 \mathrm{mg})$ and compound $5(50 \mathrm{mg})$. The fraction eluted with $60 \%$ ethanol solution was purified repeatedly through silica gel column chromatography and eluted with petroleum ether-acetone $(20: 1)$ to give compound $2(50 \mathrm{mg})$ and compound $3(100 \mathrm{mg})$. The fraction eluted with $30 \%$ aqueous solutions of ethanol was subjected to column chromatography on MCI gel, gradient-eluted with aqueous solutions of ethanol $(40 \%, 50 \%, 60 \%, 70 \%$, and $80 \%)$, and recrystallized repeatedly with methanol to give compound $1(5 \mathrm{~g})$.

2.3.2. Structural Identification (Figure 1). Compound 1: white powder, mp. $259 \sim 261^{\circ} \mathrm{C} .{ }^{1} \mathrm{H}-\mathrm{NMR}\left(\mathrm{DMSO}_{-} \mathrm{d}_{6}\right) \delta: 7.74(1 \mathrm{H}, \mathrm{d}$,
$J=8.6 \mathrm{~Hz}, \mathrm{H}-10), 7.16(1 \mathrm{H}, \mathrm{s}, \mathrm{H}-13), 6.90(1 \mathrm{H}, \mathrm{d}, J=8.4 \mathrm{~Hz}$, $\mathrm{H}-11), 6.72(1 \mathrm{H}, \mathrm{s}, \mathrm{H}-8), 5.23\left(1 \mathrm{H}, \mathrm{t}, J=7.0 \mathrm{~Hz}, \mathrm{H}-2^{\prime}\right), 3.96$ $\left(3 \mathrm{H}, \mathrm{OCH}_{3}\right), 3.36\left(2 \mathrm{H}, \mathrm{d}, J=7.0 \mathrm{~Hz}, \mathrm{H}-1^{\prime}\right), 1.78\left(\mathrm{~s}, \mathrm{CH}_{3}\right), 1.70$ $\left(\mathrm{s}, \mathrm{CH}_{3}\right)$. The above $\mathrm{H}-\mathrm{NMR}$ spectral data were consistent with the reported liquiritigenin data [8], so the compound was identified as liquiritigenin.

Compound 2: white powder, mp. $207 \sim 209^{\circ} \mathrm{C} .{ }^{1} \mathrm{H}-\mathrm{NMR}$ $\left(\mathrm{DMSO}_{-} \mathrm{d}_{6}\right) \delta: 10.66(\mathrm{~s}, \mathrm{OH}-7), 7.49\left(2 \mathrm{H}, \mathrm{d}, J=8.4 \mathrm{~Hz}, \mathrm{H}^{\prime}-2^{\prime}\right.$, 6), $7.69(1 \mathrm{H}, \mathrm{d}, J=8.6 \mathrm{~Hz}, \mathrm{H}-5), 7.10\left(2 \mathrm{H}, \mathrm{d}, J=7.2 \mathrm{~Hz}, \mathrm{H}-3^{\prime}, 5^{\prime}\right)$, $6.50(1 \mathrm{H}, \mathrm{d}, J=8.6 \mathrm{~Hz}, \mathrm{H}-6), 6.34(1 \mathrm{H}, \mathrm{s}, \mathrm{H}-8), 5.55(1 \mathrm{H}, \mathrm{brd}, J$ $=12.4 \mathrm{~Hz}, \mathrm{H}-2), 2.76(2 \mathrm{H}, \mathrm{m}, \mathrm{H}-3), 4.92(1 \mathrm{H}, \mathrm{d}, J=6.2 \mathrm{~Hz}, \mathrm{H}-$ $\left.1^{\prime \prime}\right)$. The above H-NMR spectral data were consistent with the reported liquiritin data [9], so the compound was identified as liquiritin.

Compound 3: yellow powder. ${ }^{1} \mathrm{H}-\mathrm{NMR}\left(\mathrm{DMSO}_{6} \mathrm{~d}_{6}\right) \delta$ : $13.66\left(2^{\prime}-\mathrm{OH}\right), 8.19\left(1 \mathrm{H}, \mathrm{d}, J=8.8 \mathrm{~Hz}, 6^{\prime}-\mathrm{H}\right), 7.79 \sim 7.70(4 \mathrm{H}, \alpha$, $\beta, 2,6-\mathrm{H}), 6.88(2 \mathrm{H}, \mathrm{d}, J=8.4 \mathrm{~Hz}, 3,5-\mathrm{H}), 6.38(1 \mathrm{H}, \mathrm{dd}, J=8.8$, $\left.2.4 \mathrm{~Hz}, 5^{\prime}-\mathrm{H}\right), 6.29\left(1 \mathrm{H}, \mathrm{d}, J=2.4 \mathrm{~Hz}, 3^{\prime}-\mathrm{H}\right)$. The above data were basically consistent with the isoliquiritigenin reported in the literatures $[10,11]$, so the compound was identified as isoliquiritigenin.

Compound 4: white powder (chloroform). ${ }^{1} \mathrm{H}-\mathrm{NMR}$ $\left(\mathrm{CDCl}_{3}\right) \delta: 0.66,0.74,0.82,0.88,0.92,1.66\left(\right.$ each $\left.3 \mathrm{H}, 6 \times \mathrm{CH}_{3}\right)$, $4.08(1 \mathrm{H}, \mathrm{H}-3), 4.62,4.75$ (each $\left.1 \mathrm{H}, \mathrm{C}=\mathrm{CH}_{2}\right) ;{ }^{13} \mathrm{C}-\mathrm{NMR}$ $\left(\mathrm{CDCl}_{3}\right)$ ): 38.6 (C-1), 27.6 (C-2), 76.9 (C-3), 38.7 (C-4), 55.3 (C-5), 19.0 (C-6), 34.3 (C-7), 40.6 (C-8), 51.0 (C-9), 36.9 (C10), 20.8 (C-11), 26.4 (C-12), 37.2 (C-13), 43.4 (C-14), 31.5 (C15), 32.1 (C-16), 56.3 (C-17), 49.5 (C-18), 46.8 (C-19), 150.4 (C-20), 29.7 (C-21), 38.2 (C-22), 28.0 (C-23), 15.1 (C-24), 15.9 (C-25), 16.1 (C-26), 14.9 (C-27), 179.9 (C-28), 109.9 (C-29), 19.4 (C-30). The above data were basically consistent with the reported literature [12], so compound 4 was identified as betulinic acid.

Compound 5: white powder (chloroform). ${ }^{1} \mathrm{H}-\mathrm{NMR}$ $\left(\mathrm{CDCl}_{3}\right) \delta: 0.76(3 \mathrm{H}, \mathrm{s}, \mathrm{H}-23), 0.81(3 \mathrm{H}, \mathrm{s}, \mathrm{H}-24), 0.90(3 \mathrm{H}$, s, H-25), 0.92 (3H, s, H-26), 0.93 (3H, s, H-29), 0.99 (3H, s, H-30), 1.13 (3H, s, H-27), 5.29 (1H, t, $J=2.4 \mathrm{~Hz}, \mathrm{H}-12), 3.22$ $(1 \mathrm{H}, \mathrm{dd}, J=4.2,11.4 \mathrm{~Hz}, \mathrm{H}-3 \alpha), 2.84(1 \mathrm{H}, \mathrm{dd}, J=13.8,3.6 \mathrm{~Hz}$, $\mathrm{H}-18) ;{ }^{13} \mathrm{C}-\mathrm{NMR}\left(\mathrm{CDCl}_{3}\right) \delta: 39.2$ (C-1), 26.9 (C-2), 79.1 (C-3), 38.7 (C-4), 55.5 (C-5), 18.3 (C-6), 32.6 (C-7), 40.1 (C-8), 47.7 (C-9), 37.1 (C-10), 23.5 (C-11), 122.6 (C-12), 143.6 (C-13), 41.6 (C-14), 27.7 (C-15), 23.7 (C-16), 46.5 (C-17), 41.9 (C-18), 45.9 (C-19), 30.9 (C-20), 34.8 (C-21), 33.4 (C-22), 29.1 (C-23), 15.7 (C-24), 16.3 (C-25), 18.1 (C-26), 26.2 (C-27), 183.2 (C-28), 33.1 (C-29), 23.2 (C-30). The above data were consistent with the reported literature [13], and Rf value and spot color on TLC were exactly identical with those of oleanolic acid reference substance, so compound 5 was identified as oleanolic acid.

\subsection{Anticancer Pharmacological Activity Test}

2.4.1. Preparation of Primary Hepatoma Cells. Surgically resected hepatoma tissues were taken and soaked in sterile Hanks' solution; small amounts of nonnecrotic carcinoma tissues were selected, repeatedly washed in RPMI-1640 medium containing $1 \%$ double-antibody, cut into $1 \mathrm{~mm}^{3}$ pieces, then digested by addition of a 10 -fold amount of $0.25 \%$ trypsin solution and $0.02 \%$ EDTA at $37^{\circ} \mathrm{C}$ for $35 \mathrm{~min}$, and shaken every $5 \mathrm{~min}$; digestion solutions were discarded, and the 
<smiles>O=C1CC(c2ccc(O)cc2)Oc2cc(O)ccc21</smiles>

Compound 1<smiles>O=C1C[C@H](c2ccc(Cl)cc2)Oc2cc(O)ccc21</smiles>

Compound 2<smiles>CC(=O)O</smiles>

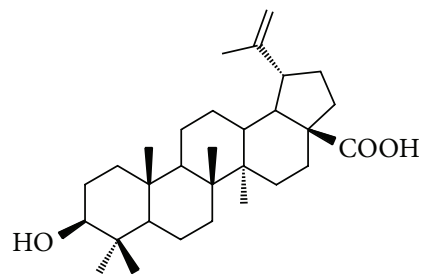

Compound 4

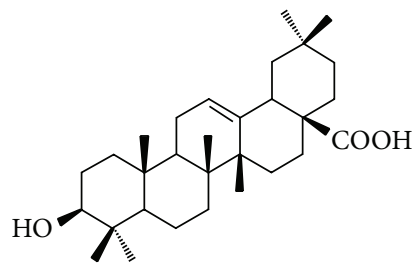

Compound 5

FIgURE 1: Structural formulas of compounds 1-5.

remaining was washed by addition of blank culture medium, then added with a small amount of culture solution, and repeatedly blown with a pipette into single cells, which were then passed through a 40 -mesh sieve, and stained with $1 \%$ trypan blue, followed by counting of the number of viable cells.

2.4.2. MTT Colorimetry. $2 \times 10^{5}$ hepatoma cell suspension was taken and seeded in 96-well plastic culture plates. Wells contained different drugs at $100 \mu \mathrm{L}$ per well, with $90 \mu \mathrm{L}$ added medium and $10 \mu \mathrm{L}$ drug; the concentration of all drugs is $1 \mathrm{mg} / \mathrm{mL}$. 10 replicate wells were set up for each drug; the plates were statically cultured in a $\mathrm{CO}_{2}$ incubator set at $37^{\circ} \mathrm{C}$ for $24 \mathrm{~h}$. After incubation, MTT reagent was added at $20 \mu \mathrm{L} /$ well, and the cultivation was continued for an additional $6 \mathrm{~h}$, then the supernatant was aspirated, and each well was added with dimethyl sulfoxide at $150 \mu \mathrm{L} /$ well and shaken for $15 \mathrm{~min}$, so that the MTT reduction product was completely dissolved. Absorbance ( $A$ value) of each well was measured at $570 \mathrm{~nm}$ using a microplate reader, and the proliferation inhibition rates against hepatoma cells by different drugs were calculated according to the following formula. Hepatoma cell proliferation inhibition rate $=(1-$ $A$ value of cells in treated wells $\div A$ value of cells in control wells) $\times 100 \%$.

2.4.3. Flow Cytometry. Changes in each cell cycle phase of primary hepatoma cells by different drugs were detected using flow cytometry. Cell culture and grouping methods were the same as "MTT colorimetry," with the exception that 96-well plastic plates were replaced by $25 \mathrm{~mL}$ culture flasks; after cultivation, cells were collected and washed three times with PBS; supernatant was discarded and the remaining was fixed in $70 \%$ cold ethanol and stored within $4^{\circ} \mathrm{C}$; before being subjected to flow cytometry, the cells were passed through a 40 -mesh sieve, concentration adjusted to $1 \times 10^{6}$ cells $/ \mathrm{mL}$, and PI stained, followed by detection with flow cytometry; cell cycle results were analyzed using Modiffi 2.0 software.
2.5. Statistical Processing. Data were analyzed using SPSS 11.0 statistical software, comparison of cell proliferation inhibition rate was performed by Student's $t$-test, and comparison of cell cycle between groups by $F$ test. All data are expressed as mean \pm standard deviation $(\bar{x} \pm s)$.

\section{Results}

Positive control 5-FU is effective for inhibiting primary hepatoma cells. Comparing with 5-FU, liquiritigenin also had apparent proliferation inhibitory effects on primary hepatoma cells, while liquiritin and isoliquiritigenin had relatively low sensitivities to hepatoma cells, and betulinic acid and oleanolic acid had no clear effect on these cells. 5-FU and liquiritigenin could significantly inhibit hepatoma cell progression from G1 phase to S phase, where G0/G1 phase cells increased, $S$ phase cells decreased, and G2/M phase cells relatively increased. See Tables 1 and 2.

\section{Discussion}

Ideal goal of adjuvant cancer chemotherapy is to pick out the most sensitive and most effective adjuvant chemotherapy regimens based on clinical manifestations, pathological type, and genetic characteristics of patients, thus ensuring maximum benefit for patients and achieving truly individualized treatment [14]. In this study, hepatoma tissues obtained from surgical resection were used to prepare single cell suspension and for primary cell culture, and drug sensitivity in cells was observed; MTT results showed that 5-FU and liquiritigenin had apparent inhibitory effects on primary hepatoma cells, with the inhibition rates of $42.9 \%$ and $35.7 \%$, respectively, while the inhibition rates of drugs in other groups were not high. Difference in the sensitivity of various drugs was larger between the groups. Therefore, sensitivity of chemotherapeutic drugs should be tested before application to facilitate the individualized treatment for the same patient, in order to 
TABLE 1: Primary hepatoma cell proliferation inhibition rates of various drugs $(\bar{x} \pm s, \%)$.

\begin{tabular}{|c|c|c|c|c|}
\hline Group & Concentration $(\mu \mathrm{g} / \mathrm{mL})$ & $A$ value & Inhibition rate (\%) & $P$ value \\
\hline Control group & 0 & $1.4 \pm 0.1$ & - & - \\
\hline 5-FU group & 10 & $0.8 \pm 0.2$ & 42.9 & $<0.01$ \\
\hline Liquiritigenin group & 100 & $0.9 \pm 0.2$ & 35.7 & $<0.01$ \\
\hline Liquiritin group & 100 & $1.0 \pm 0.0$ & 28.6 & $<0.05$ \\
\hline Isoliquiritigenin group & 100 & $1.0 \pm 0.2$ & 28.6 & $<0.05$ \\
\hline Betulinic acid group & 100 & $1.3 \pm 0.2$ & 7.1 & $>0.05$ \\
\hline Oleanolic acid group & 100 & $1.3 \pm 0.1$ & 7.1 & $>0.05$ \\
\hline Extract group & 100 & $1.2 \pm 0.3$ & 14.3 & $>0.05$ \\
\hline
\end{tabular}

TABLE 2: Effects of various drugs on cell cycle phases of primary hepatoma cells $(\bar{x} \pm s, \%)$.

\begin{tabular}{|c|c|c|c|c|c|c|c|}
\hline Group & Concentration $(\mu \mathrm{g} / \mathrm{mL})$ & G0/G1 & $P$ value & $S$ & $P$ value & $\mathrm{G} 2 / \mathrm{M}$ & $P$ value \\
\hline Control group & 0 & $26.7 \pm 4.3$ & & $68.5 \pm 3.2$ & & $5.8 \pm 1.3$ & \\
\hline 5-FU group & 10 & $58.7 \pm 3.6$ & $<0.01$ & $26.7 \pm 3.2$ & $<0.01$ & $14.3 \pm 3.2$ & $<0.05$ \\
\hline Liquiritigenin group & 100 & $55.9 \pm 4.1$ & $<0.01$ & $28.7 \pm 1.2$ & $<0.01$ & $14.8 \pm 0.3$ & $<0.05$ \\
\hline Liquiritin group & 100 & $39.8 \pm 2.3$ & $<0.05$ & $49.2 \pm 1.1$ & $<0.05$ & $11.2 \pm 0.6$ & $<0.05$ \\
\hline Isoliquiritigenin group & 100 & $38.5 \pm 3.1$ & $<0.05$ & $49.3 \pm 1.5$ & $<0.05$ & $12.3 \pm 0.4$ & $<0.05$ \\
\hline Betulinic acid group & 100 & $30.7 \pm 3.2$ & - & $63.5 \pm 2.0$ & - & $6.5 \pm 0.6$ & - \\
\hline Oleanolic acid group & 100 & $28.5 \pm 3.1$ & - & $64.6 \pm 1.6$ & 一 & $6.8 \pm 0.2$ & - \\
\hline
\end{tabular}

reduce blind medication, thereby improving the quality of treatment and enhancing survival rate. MTT assay results can objectively reflect the activation state of tumor cells, because the MTT reagent can be reduced to blue formazan particles by dehydrogenases in the mitochondria of living cells of mammals, and the amount of formazan production is linearly correlated with the number of living cells and cell activation state; this experiment is widely used in the screening of anticancer drugs and the experimental studies of cytotoxicity.

Flow cytometry results showed that different drugs all had effects on each cell cycle phase of primary hepatoma cells, but the sensitivities of 5-FU and liquiritigenin were higher. 5-FU converts into fluorouracil deoxynucleotide in the body and specifically binds with thymidylate synthase, thus affecting cell DNA synthesis; so the results showed an increase in G1 phase cells, resulting in accumulation of G1 phase cells and failure to enter $S$ phase; $S$ phase cells decreased, so that the $\mathrm{G} 2 / \mathrm{M}$ phase cells were relatively increased, while the increase in G2/M phase cells is a common reaction of cell damage [15]. Numerous studies have shown that [16] the tumor cell killing effects of many chemotherapeutic drugs are achieved by arresting cell cycle progression. Therefore, drug susceptibility testing prior to chemotherapy can not only achieve specific killing of tumor cells, but also help avoid damage to normal tissues and organs. The present study not only found that liquiritigenin has a potential antihepatoma activity, but also stressed the importance of susceptibility in the clinical treatment of cancer.

\section{Conflict of Interests}

The author declares that there is no conflict of interests regarding the publication of this paper.

\section{References}

[1] Chinese Pharmacopoeia. Volume I, p. 80-81, 2010.

[2] H. M. A. Al-Hazimi and N. A. Al-Jaber, "Phenolic compounds from Glycyrrhiza plants (Leguminosae), review article," Journal of Saudi Chemical Society, vol. 9, no. 2, pp. 347-352, 2005.

[3] G. Xing, N. Li, T. Wang, and M. Yao, "Advances in studies on flavonoids of licorice," Journal of Chinese Medicinal Materials, vol. 28, no. 7, pp. 596-597, 2003.

[4] Q. Zhang and M. Ye, "Chemical analysis of the Chinese herbal medicine Gan-Cao (licorice)," Journal of Chromatography A, vol. 1216, no. 11, pp. 1954-1969, 2009.

[5] D. Wang, J. H. Lu, Y. Liu et al., "Liquiritigenin induces tumor cell death through mitogen-activated protein kinase- (MPAKs-) mediated pathway in hepatocellular carcinoma cells," BioMed Research International, vol. 2014, Article ID 965316, 11 pages, 2014.

[6] W. Kai, X. Xiaojun, P. Ximing, H. Zhenqing, and Z. Qiqing, "Cytotoxic effects and the mechanism of three types of magnetic nanoparticles on human hepatoma BEL-7402 cells," Nanoscale Research Letters, vol. 6, article 480, 10 pages, 2011.

[7] X. Zhang, M. Zhao, L. Chen et al., "A triterpenoid from thalictrum fortunei induces apoptosis in BEL-7402 cells through the P53-induced apoptosis pathway," Molecules, vol. 16, no. 11, pp. 9505-9519, 2011.

[8] M. C. Eun, "Liquiritigenin isolated from Glycyrrhiza uralensis stimulates osteoblast function in osteoblastic MC3T3-E1 cells," International Immunopharmacology, vol. 12, no. 1, pp. 139-143, 2012.

[9] C. Sun, Y. Xie, Q. Tian, and H. Liu, "Separation of glycyrrhizic acid and liquiritin from licorice root by aqueous nonionic surfactant mediated extraction," Colloids and Surfaces A: Physicochemical and Engineering Aspects, vol. 305, no. 1-3, pp. 42-47, 2007.

[10] S. Kazuhiro, M. Yoh-ichi, M. Kana, K. Chiaki, and M. Takanao, "Synthesis and antibacterial activity of chalcones bearing prenyl 
or geranyl groups from Angelica keiskei," Tetrahedron, vol. 67, no. 29, pp. 5346-5359, 2011.

[11] T. Yin, H. Liu, B. Wang, G. Tu, H. Liang, and Y. Zhao, "Chemical constituents from Spatholobus sinensis," Acta Pharmaceutica Sinica, vol. 43, no. 1, pp. 67-70, 2008.

[12] J. F. Hu, Z. L. Ye, and F. J. Shen, "New triterpenoidal sapogenins from the roots of Glycyrrhiza yunnanensis," Acta Pharmaceutica Sinica, vol. 20, no. 1, pp. 27-30, 1995.

[13] X. J. Ding, Z. Chen, and X. Li, "Studies on the chemical constituents from Pulsatilla chinensis (Bunge) Regel," Chinese Traditional and Herbal Drugs, vol. 41, no. 12, pp. 1952-1956, 2010.

[14] J. A. Petrek, M. J. Naughton, L. D. Case et al., "Incidence, time course, and determinants of menstrual bleeding after breast cancer treatment: a prospective study," Journal of Clinical Oncology, vol. 24, no. 7, pp. 1045-1051, 2006.

[15] E. Z. Heidrun, K. Hajime, Y. Eitaro, T. Kazutake, T. Kazuo, and N. Eisuke, "Ste20-like kinase(SLK), a regulatory kinase for pololike Kinase (PLK) during the G2/M transition in somatic cells," Genes to Cells, vol. 5, no. 6, pp. 491-498, 2008.

[16] S. X. Yang, J. P. Costantino, C. Kim et al., "Akt phosphorylation at Ser473 predicts benefit of paclitaxel chemotherapy in nodepositive breast cancer," Journal of Clinical Oncology, vol. 28, no. 18, pp. 2974-2981, 2010. 

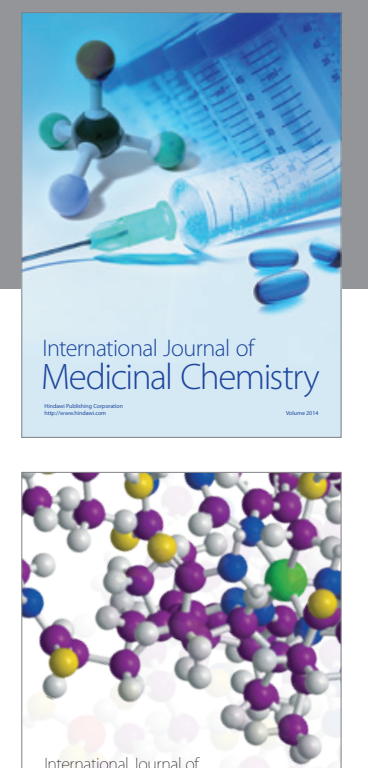

\section{Carbohydrate} Chemistry

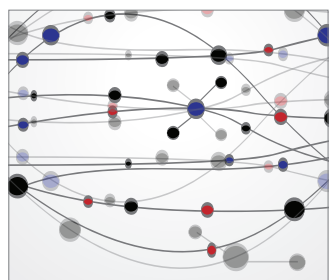

The Scientific World Journal
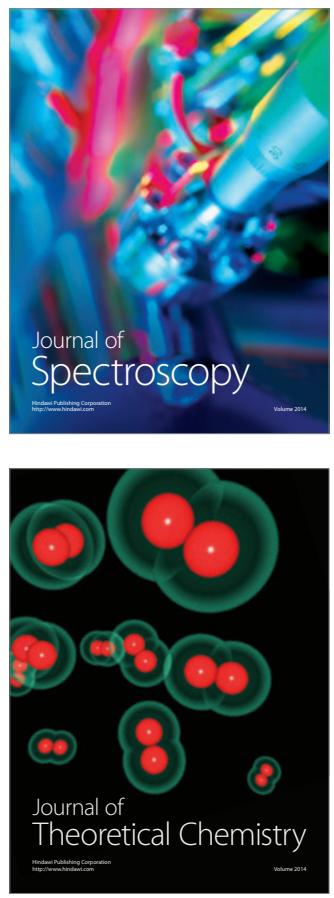
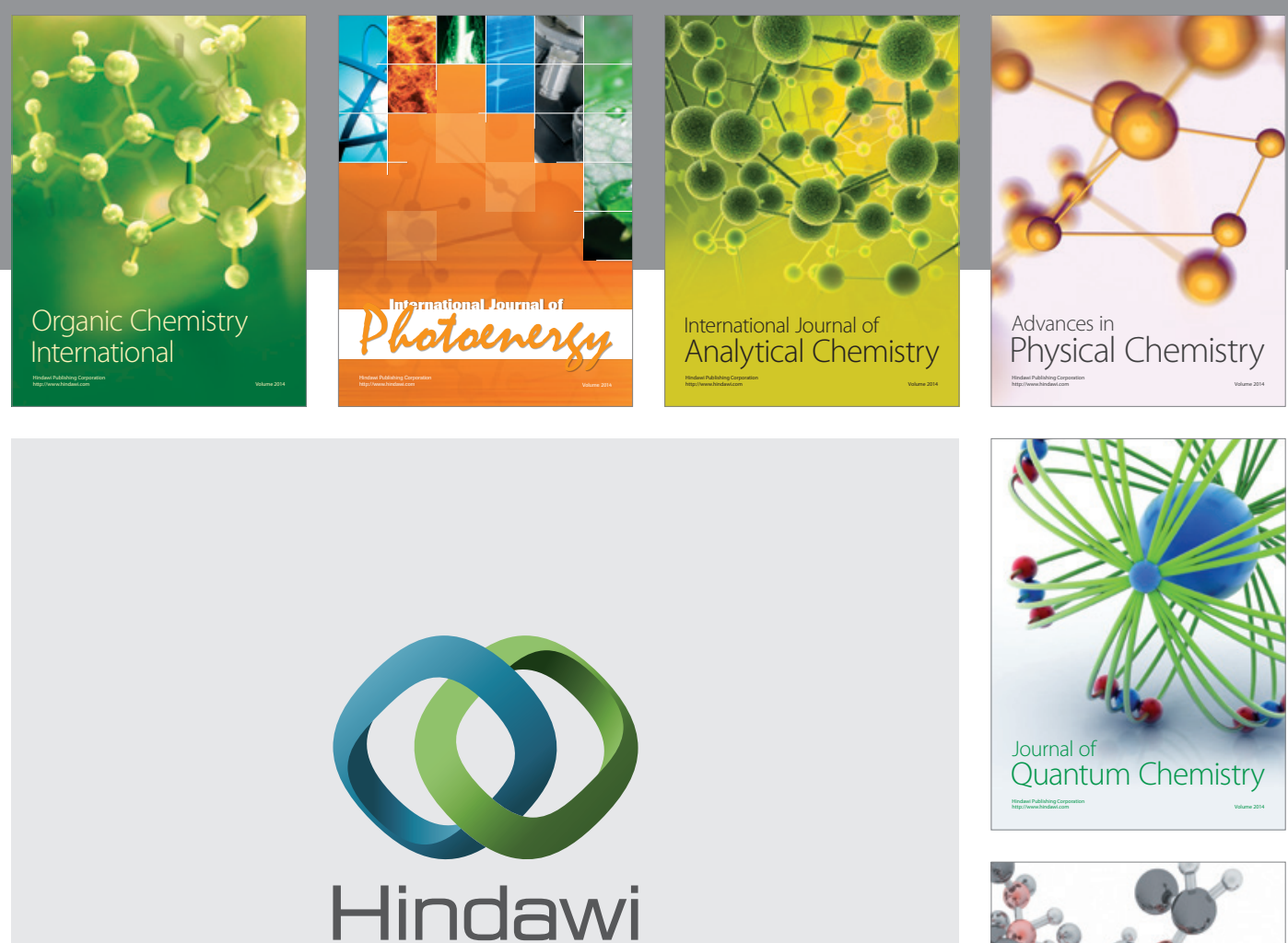

Submit your manuscripts at

http://www.hindawi.com

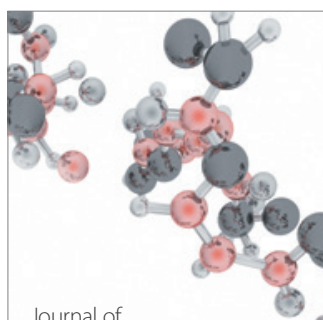

Analytical Methods

in Chemistry

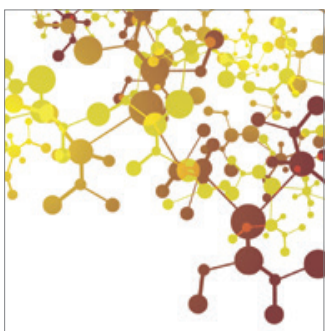

Journal of

Applied Chemistry

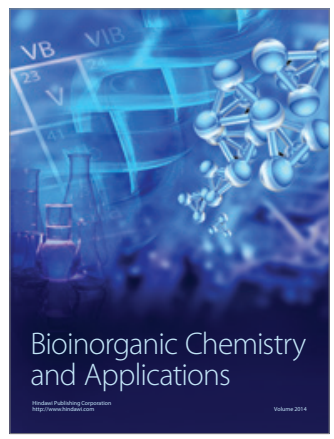

Inorganic Chemistry
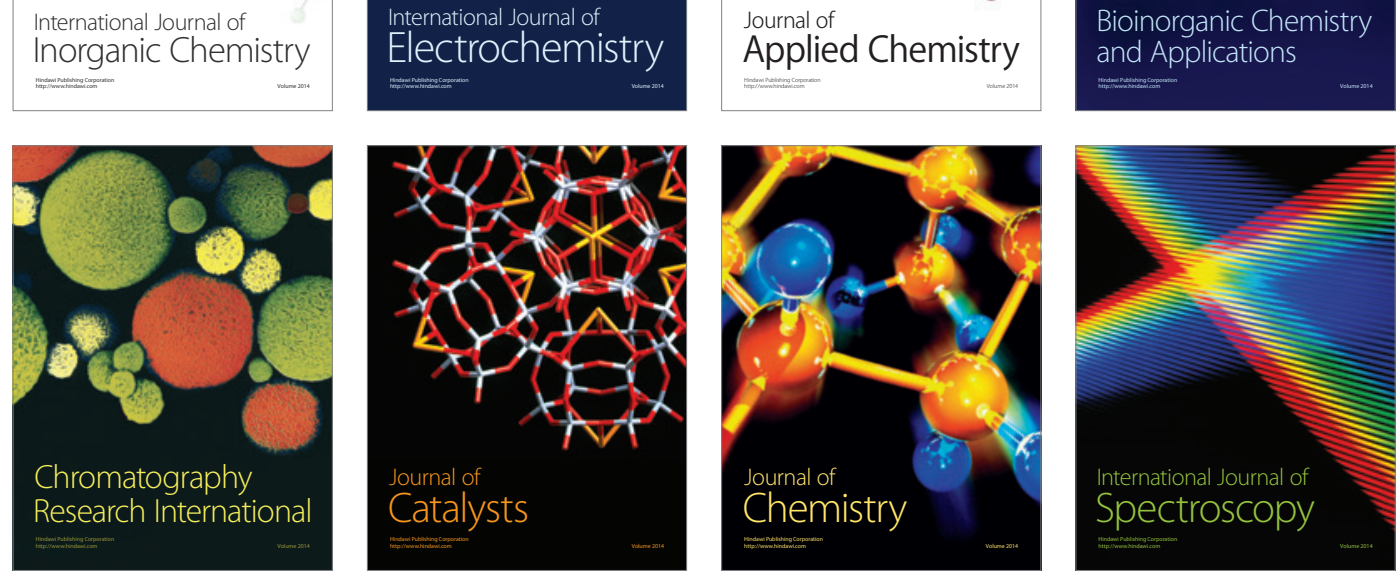